\title{
Evaluating the Benefits of Joint-use Libraries
}

\author{
Philip Calvert
}

victoria.calarco@gmail.com

Victoria University of Wellington

Keywords: Joint-use libraries, evaluation, New Zealand

\begin{abstract}
The project seeks ideas for evaluating joint-use libraries; here, libraries jointly administered by a public library and a school. 'Collaborative advantage' occurs when each partner brings something the other does not have. The evidence suggests that schools think the partnership helps them to provide a library at reduced cost while the public libraries consider it a way to extend their community reach. Do these different aims make it difficult to produce formative evaluation methods? The project discovered, however, that the most important benefit for both parties was better integration between the school and the community.
\end{abstract}

\section{Problem Statement}

A joint-use library is typically the result of a partnership between different organisations that agree to share resources to provide services through a single library building. The most common type of agreement is between a public library funded by a government authority and a school funded by the government or some other agency, with the library building located on school grounds. To refine this further, most joint-use libraries in New Zealand are partnerships between a public library and a primary school, though there is one public library and secondary school agreement (Matthews \& Calvert, 2007) and one public and tertiary academic joint use library (Calvert, 2010). The partnerships formed to manage the joint-use libraries that were the subject of this project have 'explicit' relationships (Roberts \& Bradley, 1991), that is, there are no hidden partners, and the agreement exists only for the purpose of managing the library.

There is now an extensive literature on joint-use libraries but there has been little consideration of what happens after the partnership has been running for some time; often a dangerous time when the partners start to see more disadvantages than advantages. There is a gap in our knowledge about the how partners assess the benefits that accrue from such an arrangement. There is little literature on the evaluation of joint-use libraries to help partners assess whether they are getting value from their contribution to the agreement. An honest report on a joint-use library involving two university libraries and the library of Montgomery County Public Schools (Maryland, USA) concluded that the project had largely failed because "each institution pursued a different objective" (Munster, 2017, p. 192). That ought not to be a cause for failure, as this paper will explain, but tellingly no evaluation was done, except for same simple quantitative counts, and "what needed to be adequately assessed was whether the results of the merger benefitted the institutions involved" (Munster, 2017, p. 191). This project is an attempt to make some tentative suggestions how partners in a joint-use library might evaluate the benefits that it brings. 


\section{Literature Review}

\section{The Benefits of Joint-use Libraries}

The literature has thoroughly described most benefits of joint-use libraries, so the reader can pursue the references provided in this section to explore the topic in more detail. The are several benefits and they vary in nature; many are about money and using resources efficiently. There is always some overlap between themes, but the groupings give an idea of the range of anticipated benefits.

\section{Funding}

One of the obvious benefits is that a joint-use library makes it possible to offer a public library service where none would otherwise be economically viable: "operating a partnership library offers a formula as an economically feasible way to provide library service where none exists" (Honig-Bear, 2001, p. 6). A typical arrangement is that the school provides the building, while the public library provides much of the collection and staff in a location it would otherwise not serve. The caveat is that sharing will not cost less money but "together you will be able to provide more resources to each constituent's base than if you worked separately" (Imhoff, 2001. p. 23).

\section{Resource Provision}

By combining the collections and resources, a better service can be provided. The combined collection can be more diverse if you avoid duplication. The purchase of basic, yet expensive, reference materials can be divided between the partners. Photocopiers and printers can be shared. The library can use a single library management system, generally the one provided by the public library (so a cost saving to the school) and customers should be able to identify and borrow items from both collections.

\section{The Building}

The school will usually provide the building. This saves on capital costs for one partner, and flowing on from that, on building maintenance costs (Munster, 2017). Schools in rural areas are easily accessible to the local community in terms of driving and parking (Imhoff, 2001). Occasionally other facilities are accessible from the library, such as meeting rooms and cafes. Unfortunately, sharing the building can result in disputes over who pays for power, cleaning and so on, even for consumable such as toilet rolls.

\section{Staffing and Opening Hours}

School libraries do not always employ qualified librarians, but if the public library is involved it will likely provide its own staff to work in the joint-use library. This usually provides a raised level of expertise. It might mean that the library can provide information literacy training and other programmes for the school (Olliver \& Anderson, 2001). As with the building, deciding which partner pays the staff can cause disputes.

School libraries often closes at the end of the school day and this might preclude access by the local community. By providing staff the public library makes it possible to extend opening hours. The presence of trained librarians also makes it more likely that community-based events and programmes will be run.

It can be difficult for some staff to serve two masters, and questions might arise about employee loyalty/satisfaction in a joint-use library because "employee satisfaction is strongly affected by the organisation's philosophy on empowerment ..." (Hill \& Alexander, 2000, p. 27).

\section{Theoretical Basis}

A concept used in this project is the Theory of Collaborative Advantage proposed by Huxham and Vangen (2005). Collaborative advantage, they argue, does not come from similar agencies working 
together. "There is a fundamental paradox at the heart of collaboration" (p. 82) they claim, for the real benefits of working together come from finding synergy in the differences between the organisations: different resources and different expertise. School libraries, as an example of similar organisations, often do not work together, perhaps because there is little to gain. By contrast, partnerships that bring together different types of organisations that can bring different resources to the table (e.g. one has the building, the other has staff), have more likelihood of succeeding. Provided each one perceives that it gets some benefits from the agreement, then there is collaborative advantage. Seen from the customer's point of view "Joint use libraries are successful when the patrons of each library believe that the library functions well for them: (Dornseif, 2001, p. 103).

\section{Methods of Evaluation}

Traditional performance measures in school and public libraries rely upon input data (e.g. expenditure, collection size, user space) and output data (e.g. item loans, door counts). They have their place in evaluation, despite having flaws. Generally, they are simple (and cheap) to collect and can be used by management for tracking trends in performance. Critics say they do not show how customers benefit from its services (Closter 2015), so measuring outcomes is preferable. Outcomes measures are very much harder to design, and often to collect, yet they should be part of the suite of measures collected by all libraries. One of the few references to joint-use library outcomes comes from Peterson and Breivik (2001, p.127). "Our good planning work will be measured by examining the appropriateness and extent of service outcomes to students, faculty, and community". They ask, are students are learning information literacy in order to achieve success? Is the library website usable and informative? Do parents find materials for their children and themselves? Is library programming useful to the community? Do librarians work productively with teachers on a curriculum that makes best use of library resources? Squires (2009) points to the value of council library staff knowing the curriculum.

Evaluation approaches are typically divided into two main groups: formative evaluations that examine a program being delivered in order to strengthen it or make improvements, and summative evaluations that examine the effects or outcomes of a programme after it has been delivered (Dorner, Gorman \& Calvert, 2015). Aims are used by management for regular formative evaluations, such as measuring the degree to which an aim has been achieved over the course of a year according to qualitative and quantitative data collected on performance. If it could be shown that a joint-use library has aims common to all partners, then devising agreed measures of value might be straightforward.

Before this is contemplated, however, it must be asked if a joint-use library is like many other forms of collaboration in which there are no (or very few) common aims, thus making simple formative evaluation impossible. According to Huxham and Vangen (2005, p. 84) there is a difference between 'collaboration aims and 'organisation aims'. In most partnerships it is the organisational aims that dominate: these are the aspirations of each separate organisation involved in the partnership, each one wishing to find the benefits that come from the differences between the organisations rather than their similarities.

This sets the purpose of this project; to uncover what each partner in a joint-use library wants to gain from it, and then to attempt to find measures appropriate to each partner's organisational aims. 


\section{Method}

Schools in New Zealand are administered by a local Board of Trustees, though most funding comes from the central government. The school can make local decisions about the employment of librarians, who are usually called 'support staff'. Public librarians are the responsibility of the local government authority (for shorthand sometimes referred to in this paper as 'the council'). The National Library provides some support for school libraries. There are about thirty joint-use libraries in New Zealand. The researcher visited six joint-use libraries in the Canterbury region of New Zealand and interviewed two school principals, three school librarians, two district library (council) managers, and the chair of a school's Board of Trustees, a total of eight interviews. Interviews generally took about one hour. Interviews were recorded and later transcribed. In the next section the following codes have been used for participants: DL $=\mathrm{a}$ district librarian; $\mathrm{SL}=$ a school librarian; $\mathrm{P}=$ a school principal; $\mathrm{BOT}=$ the chair of a Board of Trustees.

\section{Data and Discussion}

The literature gives a guide to themes that might be expected in the interviews. Funding and resource provision, the building and its location, staffing and opening hours all featured in almost all interviews. A few themes that do not appear often in the literature either came out of the interviews spontaneously or 'span off' the discussion, which is one of the advantages of using semi-structured interviews (Luo \& Wildemuth, 2017); these themes were the curriculum, and most importantly, the interaction between school and community. When asked what the biggest benefit that emerged from a joint-use library, it was the better interaction and understanding between the school and the community that was mentioned by most participants.

\section{The School and the Community}

The topic that seemed to gather the most positive responses was on the integration of the school into the community - and vice versa. This was somewhat unexpected because it doesn't feature much in the literature on joint-use libraries, concerned as most of it is with the establishment of partnership agreements. The council interviewees said that what they wanted to achieve was to make library experience normal and positive.

It is normalising it, you go to the library and the rest of the community's there, your mum and dad go. You see your grandmother and it becomes part of a very normal thing. [SL2]

The council staff know that if they can persuade schoolchildren to join the district library it has a benefit just in membership numbers.

So all the kids have library cards. It makes our membership numbers look good. [DL1]

Schools are where young people are so if you want to increase access to them, you go where they are. [BOT]

This last comment sounds eminently logical, but not something librarians always act upon.

In the schools, getting parents to the school was seen as a plus. If children used the library then they might bring family with them.

There must be some multiplier effect. [BOT]

International Association of School Librarianship

https://iasl-online.org 
There are people who would never come to the school if it wasn't for the library. It's the jewel in the crown for school community interaction. [SL1]

It gets used by people who just want to drop in, meet friends, sit down and read; read to their kids, find information, skype someone, hold business meetings, conduct assignations ... [SL3]

There's an intangible town square or market green sort of feel to it. [BOT]

Some schools, but only some, used the library for meetings, such as parent-teacher interviews. This was not only because it offers a useful space, but as a means of getting parents and caregivers into the library to see what was available. In one school the librarian ran evening classes in the library on subjects such as how to use an iPad. This brings in people previously unconnected in any way to the school. At another school the librarian was trying to encourage community groups to use the library, and some Asian clubs use it for Taekwondo and calligraphy.

We're getting people into the library who I've never seen before. [SL1]

I love the fact that the boss is very keen on making the library not a destination but just a place that people pass through. [SL1]

This can be summed up by this remark:

The community knowing the school and the school knowing the community. That both parties get to know each other. [SL3]

It is fair to balance this by the comments of one district librarian, who, when asked if the library brought the community and school closer together, said:

I'm not sure. I don't really think it does. [DL2]

This librarian believed the schools were getting more benefit than the community.

\section{The Library Location}

The location of the library building in relation to other school buildings is another topic rarely mentioned in the literature, yet it emerged as significant in the way it allowed for the school-community interaction discussed in the previous section.

The location of the library will affect how it is used. In some of the schools the library occupied a central location, which is commonly considered to be desirable. What makes a central location less suitable for a joint-use library is that it can be considered by the public as hard to access; which, even if it is only a perception, still has a force.

Initially not everyone in the community felt it was their space, they felt they were visiting someone else's home. [P2] 
If a community member wants a fiction book they've got to walk right through the library, through a class to get to it. In an ideal world I'd have us closer to the street so we're the first building they come to. [SL1]

In one case the location of the library had been deliberately changed to enhance community access. It was located on one corner of the school grounds but much closer to a road with plenty of foot traffic. The library had been built in a small complex that includes a cinema and a cafeteria, obviously intentional draws to the community. The principal was not happy about this, though.

The location makes it more community than school and I keep coming back to this because it is the school's building. [P1].

One principal referred to a Ministry of Education regulation about the 'footprint' of the school's buildings. As the school was at its maximum footprint, no more buildings could be added. If the library were to be moved off the schools' grounds it would release some of the footprint for new buildings. Clearly the principal did not see it as necessary to keep the library centrally and brought the matter back to cost.

For the District I think they're benefiting from it being on school land because it's maintained by the Ministry. [P1].

The large joint-use library is on school grounds (land provided by the school and the building by council) and very accessible by students. It is not an optimum location for the public because car parking isn't good and there isn't much foot traffic, but the choice of location was a compromise and one that seems to have worked well.

One interviewee gave a telling report on a library that was once joint-use but is not now. After the arrangement was dropped the council built a new library and usage grew rapidly. The district librarian explained:

Depending on the location of the library within the school we're challenged in terms of older people going on to it. It's a bit intimidating walking through playgrounds with teenage kids. [DL1]

So, in a new library away from the school, many people in the community felt more comfortable visiting it.

\section{Staffing}

There is no common pattern to how staff are provided for joint-use libraries. Many will have staff recruited and paid for by the council, this being seen as an advantage because such staff would most likely be trained (possibly with relevant qualifications) and would have good communication with the council's other librarians. In this study there was some variation across the libraries. In small libraries, the librarian's salary was paid partly by the school and partly by council. In the large library there were several staff, some paid by the school and some by the council.

Some librarians (not all) seemed to think that schools did not value the council staff as equals, but regarded them as 'support staff'. Indeed, the way that budgets work in New Zealand schools, library staff

International Association of School Librarianship

https://iasl-online.org 
paid by the school are categorised as 'support staff' so perhaps it is no surprise that they regard council librarians in the same way. This led to schools underusing the council's librarians

I have to say that the school probably doesn't get as much out of what they pay for as they could. We're not as integrated into the school as we could be. [DL1]

The same district librarian recognised that sometimes the librarian was the problem, as a result of reluctance to integrate fully into the school. This manifested itself in items that are placed on almost permanent reserve in the school library making it almost impossible for the public to access them

What we need is whole integration. Then you have to kinda crowbar your librarian out because they don't want to go and do it - sit in the staffroom. They become isolated. [DL1]

\section{The Curriculum}

At one school the librarian had previously been a teacher, which was one of the reasons he had been appointed, though he said he found it harder to keep up with changes in the curriculum because he could not find the time to attend school staff meetings at which new ideas were discussed.

At another:

The school librarian is in touch with various departmental heads to find out what they are doing and what sort of resources they need. [BOT]

A school librarian [SL3] saw the opportunity for council librarians to build a deeper understanding of the curriculum as a positive emerging from the arrangement (echoing the point made by Squires (2009)), not only because it could improve the library service provided in the school but it would carry over to library services in other schools.

The librarians, however, said that teachers did not use the library enough. If true, this could be for many reasons; lack of time, inertia, a failure to see any benefit, and so on. This was shared, perhaps surprisingly, by a principal.

I don't think the teachers at this point are making use of wider resources. The potential for them to outsource information and be able to get it brought into the school is underutilised. [P1]

Librarians are willing to contribute to the school, and some do. They attend staff meetings to introduce useful resources in the library. They will also teach classes in subjects such as digital literacy if asked.

\section{Opening Hours}

One of the bigger benefits to the school ought to be longer opening hours. Whereas many libraries close when the school day ends (usually at 3.00 p.m.) a joint-use library can stay open for longer in order to provide access to the community. Several schools in the study, however, stayed open to 4.00 but no later, making it questionable how many of the community could use the service in person, though one school librarian did not see it that way.

We're open for an hour after school finishes. I suppose that's the win, win thing. [SL1]

International Association of School Librarianship

https://iasl-online.org 
The problem, as might be expected, is money. Schools only wanted to pay staff for when the school was open, so would not pay for after hours or holiday opening. So, although the school valued the connection to the community it achieved through the library, it seemed to stop when it needed some financial input.

\section{Collections}

In the literature it is often said that the public library provides the bulk of the collection, this being a large gain for the school. In one district the council paid for all nonfiction and adult fiction, plus some children's and young adult fiction, so the school only bought a small amount of children's fiction. In the other district nearly all the collection is paid for by the council. Stock is rotated around. Items can be requested and will be delivered at no charge. This is, without doubt, a huge benefit for the school. When asked if the schools appreciate this, one school librarian wasn't too sure.

It is not a balanced relationship. [SL2]

One apparently small issue illustrates how the provision of collections was seen by the council. One school principal had ambitions to open a specialised programme for adults that would be connected to the school but not formally a part of it. The principal had an interest in the subject area and saw an entrepreneurial opportunity for the school to benefit. If this was done the school could certainly not afford to purchase any library books to support the programme, but the district librarian said that if a request was made, the council might well support it because that's the sort of thing it did as a matter of course.

We buy so many resources anyway we would do that anyway. A huge plus for the school. [DL2]

Senior students do a lot of their reading (etc.) online, hence wider access to electronic resources will be a benefit to the school. Online databases can be a split responsibility. This is because schools get access to a package of relevant databases through EPIC (Electronic Purchasing in Collaboration), which is "the national electronic licensing initiative that makes quality electronic resources available to New Zealanders through libraries who are consortium members" (National Library of New Zealand, 2019). The Ministry of Education pays into EPIC so that all schools can access it. This was not a cost to the individual school and it is a cost the council does not have to bear.

\section{Costs}

There might not be a more divisive issue for joint-use libraries than who pays the bills. It was an assumption brought to this research that schools would be more concerned about costs than the district libraries, and although there was some evidence to support it, the assumption was not wholly accurate. Perhaps a bigger sample size would have revealed a clearer picture, and it needs to be said that not all the participants were clear about who was paying for what.

One principal was very concerned about cost. He said the school invested over $\$ 600,000$ in building the new library, which is a large sum for a small school. He was also concerned that although the Board of Trustees owned the building, a Memorandum of Understanding between the Ministry of Education and the district council meant that the school could only charge a peppercorn rent of $\$ 1$ per year for 50 years. These would appear to be very valid concerns. Other issues for him were electricity and maintenance costs, all paid for by the school. As he has to approve maintenance expenditure he was aware of how much this cost, though could see how trivial it might sound: he said "you know - lightbulbs".

International Association of School Librarianship

https://iasl-online.org 
We've got a very clear outline of what resources we own ... this is not a big issue but depreciation of the collection is. [P2]

The same principal balanced his comments by acknowledging that the district council provided resources such as IT support. Other interviewees, if they had an opinion on the matter, accepted that the council paid for a lot and the school benefitted considerably from this input. One of the district librarians was not so concerned about costs.

I guess we don't see it in terms of cost savings. We feel it's beneficial to both of us and especially the school. [DL2]

But the other DL found the arguments becoming rather fractious.

They want to charge us for stationary. They also want to charge us for toilet paper, and for some staff and I've gone back to them and said if you do that then I have to charge you for toner, printers, Internet computers and the library management system - so let's not go there. [DL1]

In one seemingly generous offer, however, one council said it will pay for professional development costs for school library staff.

\section{Discussion}

In all the schools visited by the researcher, the joint-use arrangements were working satisfactorily for the involved parties, though some were happier than others. A common core was obviously the provision of a library service. For the school this centred on learning and literacy for the students, for the council, it was the more general provision of informal education and recreation, so there are going to be some differences in what aspects of the library service are most valued.

It is a simple fact that the school principals will always be concerned about money. Having the council provide services that the school does not have to pay for was a huge benefit, on that all the principals agreed. This was not the view from the council, though, who primarily saw the joint-use libraries as a way of providing library services to communities that otherwise could not be served. Thus, there are clear synergies between partners with different aims, so 'collaborative advantage' is evident. To support the theory, in one district there had been a joint-use library but it had been closed because neither party could see benefits, and the work involved in keeping it running as partnership had become 'collaboration inertia' (Huxham \& Vangen, 2005).

There was some relationship fatigue displayed as partners started to see the problems rather than stay focussed on the benefits. In such cases, if there are common aims that metrics could show being achieved, there may be greater willingness to accept the difficulties. Yet, there is little to suggest there is substantial commonality except in the basic provision of a core library service.

\section{Implications and Conclusions}

Typical library input and output measures do not get to the heart of a joint-use library's benefits. Yes, circulation might be higher than otherwise, but no participants saw that as significant. Costs must be measured, but the councils don't consider that as a hugely significant matter. Only measures that can evaluate the impact of learning really cross over between the partners. If it can be shown that the provision of a larger collection, a trained librarian, and adequate premises have a real impact on children's learning, then there would be common ground. Cost is a big consideration for the school, but we would

International Association of School Librarianship

https://iasl-online.org 
not want the school to measure its benefit by how much it can reduce costs. Seeing a return on investment would be a key measure for principals.

The benefits of community integration might be hard to measure because the outcomes will be largely in attitudes and opinions. Such things can be assessed, though, through surveys, interviews, and the like. Some activities, such as meetings and evening classes can be counted, or the percentage of the community taking advantage of the programmes calculated (Norman, 2013). Activities can be evaluated for their benefits by collecting narratives from those who attended (Calvert \& Goulding, 2015). Asking participants to determine their own opinion of 'benefit' will mean different sorts of views, e.g. qualifications gained, skills perceived to be learned, and even friendships made, but such is the nature of informal education (Rubin, 2006).

The library's location is best evaluated in terms of its convenience to customers and potential customers. In the school, staff and students will find a central location the best for its association with other school activities, but a central location might deter some members of the community. For the community the centre of the school could be uncomfortable. This could be measured by surveys; the questions would need to include matters such as signage, access to car parking, access to toilets, coverage in the event of rain, and so on (Cooper, 2007). It would be necessary to include non-customers in the survey to detect if the location deterred them completely from visiting the library. Internally issues such as the size of the space of study, classes and events will matter, but convenience for customers must rank the highest.

One of the most traditional of all library measures is to count the number of items in the collection. No doubt librarians will continue with this though for a joint-use library it becomes rather meaningless. The schools in the sample all knew how many items they owned but this was only a small proportion of the total collection made available to them by the district libraries. In one distrust the council had a total collection of about one million items, all of which were available to the school community upon request. Rather than counting items held within the library itself, therefore, it might be more telling to count the number of requests made from the school for items that were available in the wider collection. It this could be compared to similar counts made in school libraries that were not partnered with the council, it could reveal if more use is being made by the joint-use library.

One of the benefits of joint-use libraries often mentioned in the literature is that the council will appoint qualified libraries, where schools might not be able to do so. The libraries in this study tended to bear this out, so a simple measure that could be used is the level of qualification that the librarian holds. How much do the library staff know about the curriculum? It would be a useful measure if it could be done accurately. One of the more difficult aspects of staffing to evaluate is the willingness of staff to embrace the joint-use concept. There were comments made by interviewees that said, quite specifically, that some staff appointed by the schools favoured service to the school above that of the community. Regular performance appraisals might reveal something but unless the public complain it is unlikely this will come to a head.

\section{REFERENCES}

Calvert, P. J. (2010). Why do staff of joint-use libraries sometimes fail to integrate? Investigating cultures and ethics in a public-tertiary joint-use library. Journal of Academic Librarianship, 36(2), 133-140. doi:10.1016/j.acalib.2010.01.003

International Association of School Librarianship

https://iasl-online.org 
Calvert, P. \& Goulding, A. (2015). Narratives and stories that capture the library's worth: A qualitative approach to measuring value and impact in New Zealand's libraries. Performance Measurement and Metrics 16(3). 276-288. doi:org/10.1108/PMM-05-2015-0016

Closter, M. (2015). Public library evaluation: A Retrospective on the evolution of measurement systems. Public Library Quarterly, 34 (2): 107-123. Retrieved from doi.org/10.1080/01616846.2015.1036705

Cooper. J. (2007). How to evaluate your library's physical environment. Retrieved from http://www.infotoday.com/MLS/may07/Cooper.shtml

Dorner, D. G., Gorman G. E. and Calvert, P. J. 2015. Information needs analysis: Principles and practice in information organizations. London: Facet.

Dornseif, K. A. (2001). Libraries: Balancing autonomy and cooperation. In Miller, W. and Pellen, R. M. (eds) Joint-use Libraries. New York: Haworth, pp.103-115. Doi:10.1300/J121v15n01_08

Honig-Bear, S (2001). School-public library partnerships in Washoe County, Nevada. In Miller, W. and Pellen, R. M. (eds) Joint-use Libraries. New York: Haworth, pp.5-16.

Doi:10.1300/J121v15n01_02

Kanter, R. M. (1994). Collaborative advantage: the art of alliances; successful partnerships manage the relationship, not just the deal. Harvard Business Review, 72(4), p.96-108.

Hill, N. \& Alexander, J. (2000). Handbook of customer satisfaction and loyalty measurement. 2nd ed. Aldershot: Gower.

Huxham, C. \& Vangen, S. (2005). Managing to collaborate: The theory and practice of collaborative advantage. London: Routledge.

Imhoff, K. R. T. (2001). Public library joint-use partnership: Challenges and opportunities. In Miller, W. and Pellen, R. M. (eds) Joint-use Libraries. New York: Haworth, pp.17-39. Doi:

10.1300/J121v15n01_03

Luo, L. \& Wildemuth, B. M. (2017). Semistructured interviews. In Applications of social science research methods to questions in information and library science, ed. B.M. Wildemuth $2^{\text {nd }}$ ed, pp. 248-257. Santa Barbara, CA: Libraries Unlimited.

Matthews, V. K. D. \& Calvert, P. J. (2007). The Critical Success Factors for school and community (joint use) libraries in New Zealand. Education Libraries, 30(2), 5-17. doi:10.26443/el.v30i2.238

Munster, I. (2017). A tale of two libraries: A merger and its challenges. A case study. Journal of Library Administration, 57(2), 174-193. Doi:10.1080/01930826.2016.1222119

National Library of New Zealand. (2019). EPIC. Retrieved from https://natlib.govt.nz/librarians/epic.

Norman, M. 2013. Collaborative Libraries: Can We Do and Measure "Things" Differently? Public Library Quarterly, 32 (3), 223-239. Doi 10.1080/01616846.2013.818841

International Association of School Librarianship

https://iasl-online.org 
Olliver, J. \& Anderson, S. (2001). Seminole Community Library: Joint-use library services for the community and the college. In Miller, W. and Pellen, R.M. (eds) Joint-use Libraries. New York: Haworth, pp.89-102. doi:10.1300/J121v15n01_07

Peterson, C. \& Breivik, P. S. (2001). Reaching for a vision: The creation of a new library collaborative. In Miller, W. and Pellen, R. M. (eds) Joint-use Libraries. New York: Haworth, pp.117, doi:10.1300/J121v15n01_09

Roberts, N. \& Bradley, R. (1991). Stakeholder collaboration and innovation: A study of public policy initiation at the state level. Journal of Applied Behavioral Science, 27 (2), 209-227. Doi:10.1177/2F0021886391272004

Rubin, R. J. (2006). Demonstrating results: Using outcome measurement in your library. Chicago: ALA.

Squires, T. (2009). Library partnerships: Making connections between school and public libraries. Medford, NJ: Information Today.

Vangen, S., \& Huxham, C. (2003). Nurturing collaborative relations: Building trust in interorganizational collaboration. The Journal of Applied Behavioral Science, 39(1), 5-31. Doi $10.1177 / 0021886303039001001$

Biographical Note

Philip Calvert is a Senior Lecturer at Victoria University of Wellington, New Zealand. His publications include journals articles on the human resource in school libraries. 